\title{
Action-orientated research and framework: insights from the French long- term social-ecological research network
}

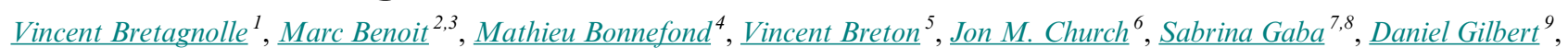

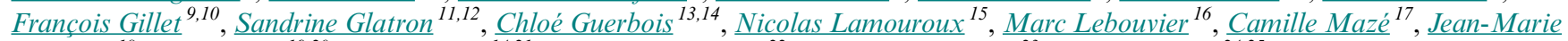 \\ Mouchel $^{18}$, Annie Ouin ${ }^{19,20}$, Olivier Pays ${ }^{14,21}$, Christophe Piscart ${ }^{22}$, Olivier Ragueneau ${ }^{23}$, Sylvie Servain ${ }^{24,25}$, Thomas Spiegelberger \\ 26,27 and Hervé Fritz ${ }^{13,14,28}$
}

\begin{abstract}
Many social-ecological system(SES)-based approaches have been proposed to address environmental problems. Most social-ecological frameworks developed to date, however, lack clear operational linkages between humans and nature to efficiently guide SESs toward resilience. A conceptual framework designed to be operational is therefore necessary, as well as a network of research platforms with which to apply it. We defined explicit coupling processes that can be used as leverages to pilot an SES toward sustainability. We proposed to formalize an SES as a dynamic entity composed of two coupling interfaces, i.e., adaptive management and ecosystem services, both set within a landscape context to provide an actionable framework. These interfaces describe the way various actors, including scholars, benefit from and manage complex and changing interactions between the biophysical and social templates. Understanding the key processes underlying the interaction dynamics, especially those leveraging adaptive management processes, would help identify adaptive pathways for practices and collective actions, provide a crucial knowledge base for policy makers, and foster operationality as a requisite of an SES research agenda. Using several examples, we explained why long-term social-ecological research platforms provide an ideal operational network of research infrastructures to conduct place-based action-orientated research targeting the sustainability of SESs.
\end{abstract}

Key Words: adaptive governance; ecosystem services; landscape; LTER; management; practices; research infrastructure; social-ecological systems; sustainability

\section{INTRODUCTION}

In the Anthropocene (Lewis and Maslin 2015), humankind's global footprint in terrestrial ecosystems gradually increased from $5 \%$ to more than $50 \%$ in just 3 centuries (Ellis et al. 2010). Already, human impacts on ecosystems worldwide have resulted in a dramatic decline in biodiversity (Pimm et al. 2014), with measurable consequences for ecosystem services (ESs; Balvanera et al. 2014). Ecosystems will be even more intensively used in the future because the human population is still growing rapidly (Carpenter et al. 2009). Altogether, increased human pressure on ecosystems, global change, finite resources, and economic instability urge decision makers to frame new paradigms for sustainable development to achieve human well-being for all (Ellis 2015). Locally relevant indicators of the system's state were developed to prompt public action (e.g., Dearing et al. 2014), but the analysis of the relationship between social and biophysical conditions at broader scales, e.g., the landscape scale, as a tool to foster changes in management from a system dynamics perspective is still lacking.

Environmental problems result from social, technical, economic, and ecological variables that not only form complex systems on their own, but also can interact to create wicked problems with intricate causes and consequences. Solving them calls for a new research posture, shifting from monodisciplinary approaches to transdisciplinarity (Jahn et al. 2012). The latter allows accounting for various and diverging viewpoints and involves explicit stakeholder knowledge, as well as cooperation between science and society (Spangenberg et al. 2015, Church 2018). Interdisciplinary and transdisciplinary research that links social and ecological systems as an integrated science-policy research agenda (Folke 2006, Ostrom 2009) also requires a dedicated research infrastructure (RI). We argue that long-term socialecological research (LTSER) platforms are such RI, sharing a

${ }^{1}$ LTSER "Zone Atelier Plaine \& Val de Sèvre," CEBC CNRS, Villiers-en-Bois, France, ${ }^{2}$ LTSER "Zone Atelier Moselle," Vandoeuvre Les Nancy, France, ${ }^{3}$ INRA, unité Aster, Mirecourt, France, ${ }^{4}$ LTSER "Zone Atelier Loire," Conservatoire National des Arts et Métiers, EA 4630 Laboratoire Géomatique et Foncier, France, ${ }^{5}$ LTSER, "Zone Atelier Territoires Uranifères," Université Clermont Auvergne, CNRS/IN2P3, LPC, ClermontFerrand, France, ${ }^{6}$ University of Reims Champagne-Ardenne, HABITER EA 2076, France, ${ }^{7}$ USC 1339, Centre d'Etudes Biologiques de Chizé, INRA, Villiers-en-Bois, France, ${ }^{8}$ LTSER "Zone Atelier Plaine \& Val de Sèvre," CNRS, Villiers-en-Bois, France, ${ }^{9}$ LTSER "Zone Atelier Arc Jurassien," Besançon, France, ${ }^{10}$ Université Bourgogne Franche-Comté, UMR CNRS 6249 Chrono-environnement, Besançon, France, ${ }^{11}$ LTSER "Zone Atelier Environnementale Urbaine," Strasbourg, France, ${ }^{12}$ Laboratoire Dynamiques Européennes, CNRS-Unistra, Strasbourg, France, ${ }^{13}$ Nelson Mandela University, Sustainability Research Unit, George Campus, George, South Africa, ${ }^{14}$ LTSER "Zone Atelier Hwange," Dete, Zimbabwe, ${ }^{15}$ IRSTEA, UR RIVERLY, Lyon, France, ${ }^{16}$ LTSER "Zone Atelier Antarctique," UMR Ecobio, Rennes, France, ${ }^{17}$ LIENSs (UMR 7266), La Rochelle, France, ${ }^{18}$ LTSER "Zone Atelier Seine," UMR METIS, Sorbonne-Université, CNRS, EPHE, Paris, France, ${ }^{19}$ UMR DYNAFOR, INRA - Toulouse INP, France, ${ }^{20}$ LTSER ZA PYAGR, Toulouse, France, ${ }^{21}$ UMR 6554 CNRS, LETG-Angers, Université d'Angers, Angers, France, ${ }^{22}$ LTSER "Zone Atelier Armorique," Univ. Rennes, UMR Ecobio, Rennes, France, ${ }^{23}$ LTSER "Zone Atelier Brest-Iroise," CNRS, IRD, Ifremer, LEMAR, Univ. Brest, Plouzane, France, ${ }^{24}$ LTSER "Zone Atelier Loire," Tours, France, ${ }^{25}$ UMR 7324 CITERES, CNRS, Tours Univ., Tours, France, ${ }^{26}$ Univ. Grenoble Alpes, Irstea, UR LESSEM, Grenoble, France, ${ }^{27}$ LTSER "Zone Atelier Alpes," Grenoble, France, ${ }^{28}$ CNRS UMR 5558, Université de Lyon 1, Villeurbanne Cedex, France 
Table 1. Description of the 14 research platforms of the French long-term social-ecological research (LTSER) network. ILTER, international long-term ecological research; SES, social-ecological system.

\begin{tabular}{|c|c|c|c|c|c|}
\hline $\begin{array}{l}\text { LTSER } \\
\text { Name }\end{array}$ & ILTER Code & $\begin{array}{l}\text { Size } \\
\left(\mathrm{km}^{2}\right)\end{array}$ & Main Ecosystem & Main Stakeholders & SES Objective \\
\hline Alpes & $\begin{array}{l}\text { LTER_EU_F- } \\
\text { R_001 }\end{array}$ & 100,000 & $\begin{array}{l}\text { Alpine pastures, heathlands, } \\
\text { and mountain forests }\end{array}$ & $\begin{array}{l}\text { National and regional parks, farmers, } \\
\text { foresters, public administrations and } \\
\text { collectivities, and researchers }\end{array}$ & $\begin{array}{l}\text { Trajectories and } \\
\text { functioning of socioeconomic } \\
\text { environments in a context of } \\
\text { climate change and territorial } \\
\text { changes }\end{array}$ \\
\hline $\begin{array}{l}\text { Arc } \\
\text { Jurassien }\end{array}$ & $\begin{array}{l}\text { LTER_EU_F- } \\
\text { R_012 }\end{array}$ & 13,500 & $\begin{array}{l}\text { Grasslands, forests, karstic } \\
\text { hydrosystems, wetlands, }\end{array}$ & $\begin{array}{l}\text { Farmers, public bodies, NGOs, cheese } \\
\text { sectors, and researchers }\end{array}$ & $\begin{array}{l}\text { Sustainable management of } \\
\text { midmountain landscapes }\end{array}$ \\
\hline Antarctique & $\begin{array}{l}\text { LTER_EU_F- } \\
\text { R_011 }\end{array}$ & 7700 & $\begin{array}{l}\text { Herb field, fell field, and polar } \\
\text { and subpolar waters }\end{array}$ & $\begin{array}{l}\text { Researchers, administration, and fishing } \\
\text { owners }\end{array}$ & Biodiversity conservation \\
\hline Armorique & $\begin{array}{l}\text { LTER_EU_F- } \\
\text { R_004 }\end{array}$ & 6750 & $\begin{array}{l}\text { Grassland, urban, forest, and } \\
\text { streams }\end{array}$ & Farmers, public bodies, and citizens & $\begin{array}{l}\text { Biodiversity conservation in } \\
\text { agricultural and urban area }\end{array}$ \\
\hline $\begin{array}{l}\text { Bassin du } \\
\text { Rhône }\end{array}$ & $\begin{array}{l}\text { LTERE_EU_F- } \\
\text { R_006 }\end{array}$ & 96,500 & $\begin{array}{l}\text { Rivers, streams, lakes, and } \\
\text { catchments }\end{array}$ & $\begin{array}{l}\text { Public administrations and collectivities, } \\
\text { hydropower companies, citizens, and } \\
\text { NGOs }\end{array}$ & $\begin{array}{l}\text { Sustainable process-based } \\
\text { management, long-term SES } \\
\text { observation, and scientific } \\
\text { federation }\end{array}$ \\
\hline Brest Iroise & $\begin{array}{l}\text { LTER_EU_F- } \\
\text { R_007 }\end{array}$ & 6690 & $\begin{array}{l}\text { Land-ocean interface, coastal } \\
\text { zone, estuaries, streams, and } \\
\text { watersheds }\end{array}$ & $\begin{array}{l}\text { Public bodies, fishers, farmers, scientists, } \\
\text { NGOs, and watershed and coastal zone } \\
\text { managers }\end{array}$ & $\begin{array}{l}\text { Facilitating transformation toward } \\
\text { sustainability of the Bay of Brest } \\
\text { and the adjacent Iroise Sea, facing } \\
\text { increasing coastal risks (erosion } \\
\text { and submersion), eutrophication, } \\
\text { and decreasing biodiversity }\end{array}$ \\
\hline $\begin{array}{l}\text { Environne- } \\
\text { ment } \\
\text { Urbain }\end{array}$ & $\begin{array}{l}\text { LTER_EU_F- } \\
\text { R_005 }\end{array}$ & 3000 & Urban and periurban & $\begin{array}{l}\text { Citizens, local researchers, public bodies } \\
\text { (town and regional authorities and air- } \\
\text { quality and environmental local } \\
\text { agencies), NGO, and enterprises } \\
\text { (buildings enterprises, planners, energy } \\
\text { providers, etc.) }\end{array}$ & $\begin{array}{l}\text { Urban sustainable development } \\
\text { considering environmental systems }\end{array}$ \\
\hline $\begin{array}{l}\text { Hwange } \\
\text { (Zimbabwe) }\end{array}$ & $\begin{array}{l}\text { LTER_EU_F- } \\
\text { R_010 }\end{array}$ & 15,000 & $\begin{array}{l}\text { Wooded semiarid savanna and } \\
\text { subsistence agriculture }\end{array}$ & $\begin{array}{l}\text { National park staff, public bodies, } \\
\text { farmers, foresters, NGOs, and tourism }\end{array}$ & $\begin{array}{l}\text { Sustainable ecosystem service } \\
\text { delivery from the protected area } \\
\text { for promoting the resilience of the } \\
\text { SES }\end{array}$ \\
\hline Loire & $\begin{array}{l}\text { LTER_EU_F- } \\
\text { R_008 }\end{array}$ & 117,000 & $\begin{array}{l}\text { River hydrosystems, forest, } \\
\text { grasslands, intensive } \\
\text { agriculture, urban, and } \\
\text { periurban }\end{array}$ & $\begin{array}{l}\text { Public bodies (state, water and } \\
\text { biodiversity agencies, regional and local } \\
\text { authorities, etc.), environmental NGOs, } \\
\text { users (farmers, tourists, fishers, etc.), and } \\
\text { citizens }\end{array}$ & $\begin{array}{l}\text { Functioning and dynamics on the } \\
\text { Loire system and understanding } \\
\text { components (abiotic, biotic, and } \\
\text { socio-systemic) and their } \\
\text { interactions over the long term }\end{array}$ \\
\hline Moselle & $\begin{array}{l}\text { LTER_EU_F- } \\
\text { R_003 }\end{array}$ & 16,500 & $\begin{array}{l}\text { Forest, mixed farming } \\
\text { systems, cities, and industries }\end{array}$ & $\begin{array}{l}\text { Water agency (Rhin-Meuse), public } \\
\text { bodies, farmers, and forestry }\end{array}$ & $\begin{array}{l}\text { Water quality and human } \\
\text { pressure: state, improvement, and } \\
\text { remediation }\end{array}$ \\
\hline $\begin{array}{l}\text { Plaine \& } \\
\text { Val de } \\
\text { Sèvre }\end{array}$ & $\begin{array}{l}\text { LTER_EU_F- } \\
\text { R_009 }\end{array}$ & 450 & $\begin{array}{l}\text { Intensive agriculture and } \\
\text { villages }\end{array}$ & $\begin{array}{l}\text { Farmers, NGOs, citizens, and public } \\
\text { bodies }\end{array}$ & $\begin{array}{l}\text { Landscape agroecology for } \\
\text { sustainable agriculture }\end{array}$ \\
\hline $\begin{array}{l}\text { Pyrénées } \\
\text { Adour } \\
\text { Garonne }\end{array}$ & $\begin{array}{l}\text { LTER_EU_F- } \\
\text { R_014 }\end{array}$ & 16,073 & $\begin{array}{l}\text { Agroecosystems (mountains } \\
\text { and valley) }\end{array}$ & Farmers, state agency, and NGO & $\begin{array}{l}\text { Resilience of SES from upstream } \\
\text { to downstream of a large river }\end{array}$ \\
\hline
\end{tabular}

unified and operational framework. We propose pathways to develop such a framework, which makes explicit the coupling interfaces between social and ecological templates to use leverage tools and promote action for active social-ecological system (SES) stewardship (Chapin et al. 2010). We analyze the case of the French LTSER RI, currently composed of 14 highly diverse research platforms (Table 1), and further argue that the RI should be organized as a network. At the local level, i.e., sites or platforms, social-ecological feedbacks can be monitored, experimented with, and predicted, whereas at the network level they can be formalized and generalized.

\section{KEY DRIVERS OF THE SOCIAL-ECOLOGICAL SYSTEM INTERFACE: CONCEPTUAL FRAMEWORK}

Most natural ecosystems have been colonized and exploited by humans, becoming SESs. SESs combine interdependent social and ecological dynamics that involve multiple interactions and feedbacks between the human and ecological components (Collins et al. 2011), are adaptive (Folke et al. 2005, Levin et al. 2013), and loop into co-occurring complex (Holling 2001) and cross-scale (Levin 1998, Cash et al. 2006) dynamics. Addressing solely the social dimension of resource management without ecosystem dynamics or focusing only on the biophysical processes as a basis for decision making for sustainability both lead to narrow conclusions that may result in unexpected outcomes and 
Fig. 1. The conceptual framework of the social ecological system (SES) within the French long-term socialecological research platforms. The SES as an entity is composed of two coupling interfaces, the adaptive management interface and the ecosystem services interface, both set within an explicit landscape context. The originality in this framework is the emphasis on explicit components that will directly contribute to changing the trajectory of the SES.

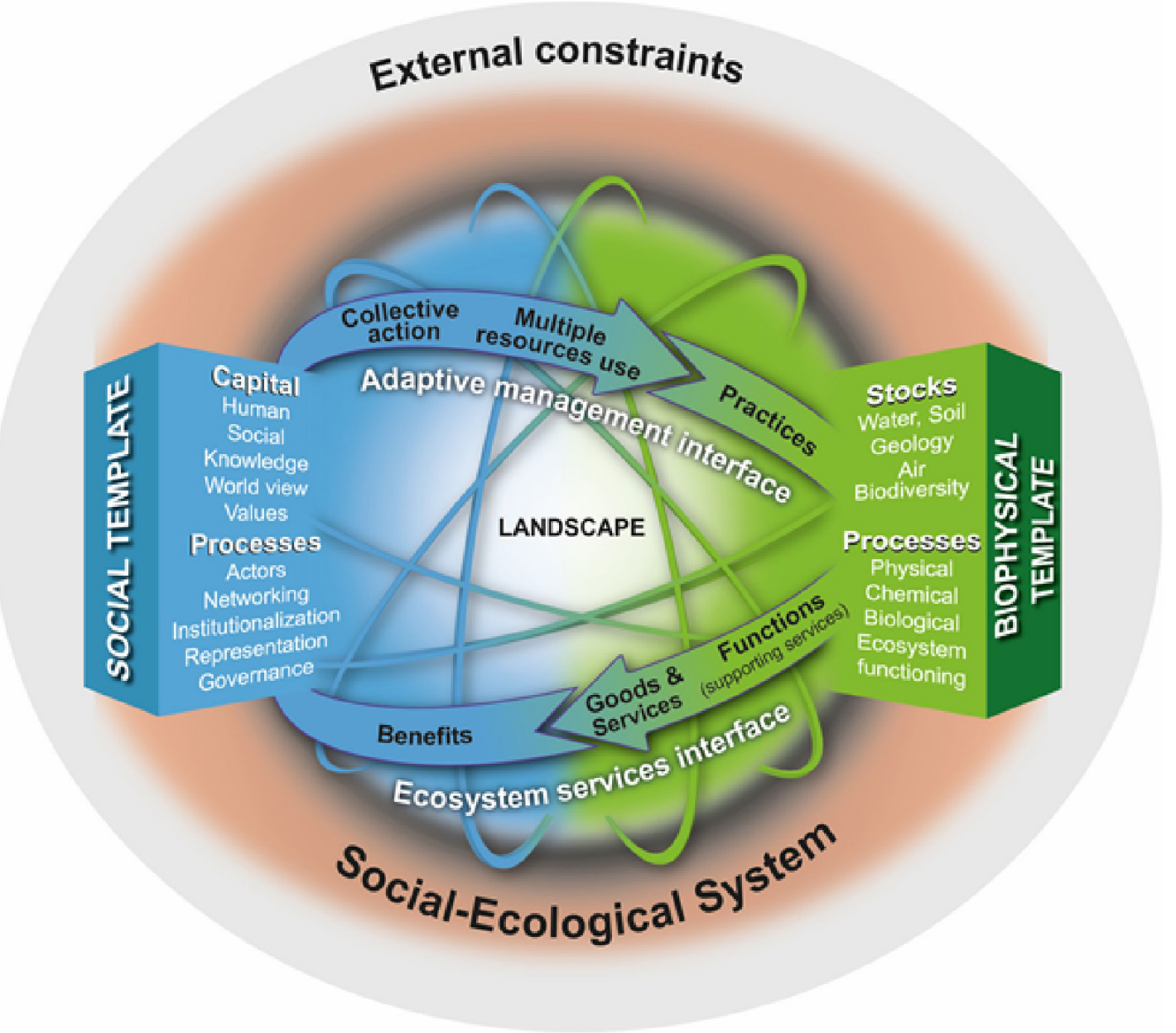

even the collapse of SESs, e.g., the Aral Sea. The system therefore needs to be considered as a whole because of the tight couplings among components and across scales (Redman et al. 2004).

Going beyond Collins et al.'s (2011) conceptual framework, we suggest that SES key elements can be coupled into two processbased interacting interfaces, each comprising three core items: the (1) "ecosystem services interface" with functions, goods, and benefits/values; and the (2) "adaptive management interface" with collective action and colearning, multiple resource uses, and practices. Both interfaces are set within a given landscape (Fig. 1). We consider these six core items as leverages influencing the dynamics of the SES, though they differ in scale and nature. The two interfaces and their core coupling elements share characteristics despite having their own variables, methods, analytic tools, vocabulary, and semantics (Abson et al. 2014, Rissman and Gillon 2017). Having many meanings, their use conveys concepts with dialectically vague frontiers. As such, they can be seen as boundary objects that can promote opportunities for transdisciplinarity (Schröter et al. 2014).

The ES interface and its elements have already been clearly identified and discussed as coupling agents in social-ecological processes (e.g., Reyers et al. 2013, Hamann et al. 2015). Conversely, the core elements of the adaptive management interface were less often considered as coupling forces in the SES, except in Ostrom's SES framework (Ostrom 2009) and, more recently, for collective action (Barnaud et al. 2018) or practices (Lescourret et al. 2015). Links between collective action and multiple resource use were also recognized to contribute to fostering adaptive governance in a context of adaptive management or comanagement (Kofinas 2009). We therefore need to specify these core elements of the adaptive management interface and their interplay in the context of our framework. 
Subsequently, we provide an overview of the framework, mainly based on theoretical considerations and literature review. Then, in Operationalizing the conceptual framework within research infrastructures, we provide examples from the French LSTER network.

\section{The adaptive management interface}

This interface, in which institutional arrangements and ecological knowledge interplay at various levels, is central to SES dynamics and their study (Folke et al. 2005). The transitions from the three core elements of this interface, i.e., collective action, multiple resource use, and practices, can be considered fuzzy (Fig. 1). Indeed, collective action can be seen as the social dimension of managing multiple uses of SESs (e.g., see Kofinas 2009), whereas individual or collective practices stem from these arrangements but are filtered through value systems and mental models. This interface thus describes a form of adaptive management of the focal SES, or even comanagement in more advanced coupling initiatives (Olsson et al. 2004). In some of the SES literature, this interface is also referred to as adaptive governance (Folke et al. 2005, Chaffin et al. 2014), which describes the links between societies and ecosystems not only as end products but also as at the very heart of social-ecological coupling. Adaptive governance focuses on experimentation and learning, bringing together research on institutions and organizations for collaboration, collective action, and conflict resolution in relation to natural resource and ecosystem management (Kofinas 2009). In many ways, adaptive governance can be considered an ideal model for SES governance (Chaffin et al. 2014).

\section{Collective action}

The concept of collective action (Olson 1971, Ostrom 1990) is used to describe the processes through which "two or more individuals cooperate to accomplish a goal they cannot achieve individually" (Matson et al. 2016:85). Within the SES framework, collective action and social relations are framed with regard to the biophysical, particularly facing environmental uncertainty, and the socio-economic contexts, in particular, public policies and market economy. It implies decision making or deliberation (Rosenberg 2007), which can be blocked or distorted by power relations, existing incentives, and limited knowledge. Implementation and evaluation processes around the policies are intended to achieve the goal of collective action, such as resilience (Mazé et al. 2017). In such a process, different communities of scientific experts, knowledge holders, and decision makers interact through different kinds of boundary objects (Brand and Jax 2007, Clark et al. 2016).

\section{Multiple resource use}

Natural resources, including land and, by extension, ESs, are used in multiple ways and, in most cases, by multiple agents. Agents can act individually or collectively and belong to different user groups (as defined by Ostrom et al. 2007). This situation of multiple use by multiple agents requires complex processes of negotiation and regulation providing rules at different levels, particularly property rights, self-organization rules, and policy outputs, among different agents for the implementation of decision making (Lascoumes and Le Gales 2007). We hold the view that the study of multiple uses can be employed not only as an analytical tool but also as a way to contribute to the management of the multiple uses of multiple natural resources.
The latter can, directly or indirectly, e.g., through a common driver, interact with each other, echoing in a way the idea of a bundle of ESs that need to be considered simultaneously rather than separately (Bennett et al. 2009). We also draw attention to collective uses stemming from negotiation and local arrangements by including them in the framework, because practical collective management has received proportionally less emphasis in adaptive management theories (but see Berthet et al. 2012).

\section{Practices}

Practices are defined as actions and measures motivated by background knowledge, cultural and technical heritage, perception, beliefs, and states of emotion (Feldman and Orlikowksi 2011). They are the primary interactions between human beings and their supporting ecosystem and happen from fine (field, neighborhood) to coarse (regions, cities) scales. Practices are effect-producing phenomena within the SES affecting the SES coupling (Lescourret et al. 2015). They directly affect a complex set of biophysical, ecological, and social features required to deliver ESs, hence impacting the resilience and sustainability of ES provision (Bennett et al. 2009). For example, in agricultural landscapes, the delivery of multiple ESs (agricultural production, pollination, and landscape aesthetics) derives from agricultural practices, such as crop species sown, the use of inputs or ploughing, and the size of fields (Tancoigne et al. 2014). In semiarid savannahs of the LTSER Hwange, animal distribution (directly related to water use), trampling, and safari experience are all conditioned by pumping practices in protected areas (Chamaillé-Jammes et al. 2007).

\section{INTEGRATING SOCIAL-ECOLOGICAL CONCEPTS WITHIN LONG-TERM ECOLOGICAL RESEARCH SITES}

Despite a few operational tools and practical guidelines that exist (Anderies et al. 2004, United Nations Development Programme 2015), SES research has remained mostly theoretical, generic, and qualitative (Nassl and Löffler 2015). The theory-to-practice gap to implement sustainable transformation is further blurred by the fact that most often, social and ecological components are not treated equally profoundly and reciprocally (Binder et al. 2013), and most of the time, the research process is considered disconnected from the system's trajectory. Although the societal component of SESs has been hardly surveyed in these areas in the long term, the ecological component has often been monitored for decades with dedicated research platforms, particularly within the long-term ecological research (LTER) network. LTER is an initiative that arose in several countries more or less simultaneously, but which really took the format of an organized network first in the United States in the 1980s (Callahan 1984). LTER sites now number almost 1000 worldwide (Mirtl et al. 2013). They were primarily chosen in natural landscapes without human activities. They were small in size and focused on monitoring physical, chemical, and biological processes. However, human and social aspects eventually gained interest, with more and more sites involving human activities (see the review by Folke et al. 2005). A very similar convergence appeared in Europe, even though the European LTER network officially started later and in a different form (Haberl et al. 2006, Mirtl et al. 2013). LTSER is a combination of SES research and LTER approaches. It emerged more or less simultaneously on the two continents (Mauz et al. 2012). 
Fig. 2. Current research investment of the 14 research platforms of the French long-term social-ecological research network for each core coupling element of the two interfaces. Several research approaches are used: formalism, observation, experimentation, and modeling. The colors indicate the levels of investment (green = high, yellow $=$ medium, and orange $=$ low) of each platform, i.e., 14 color rectangles per table cell. The resulting color mosaic per cell gives an overview of the current research strength and needs of the network. Goods and ecosystem services are split into mono- or multiecosystem services. Monetary and nonmonetary valuations of benefits are considered.

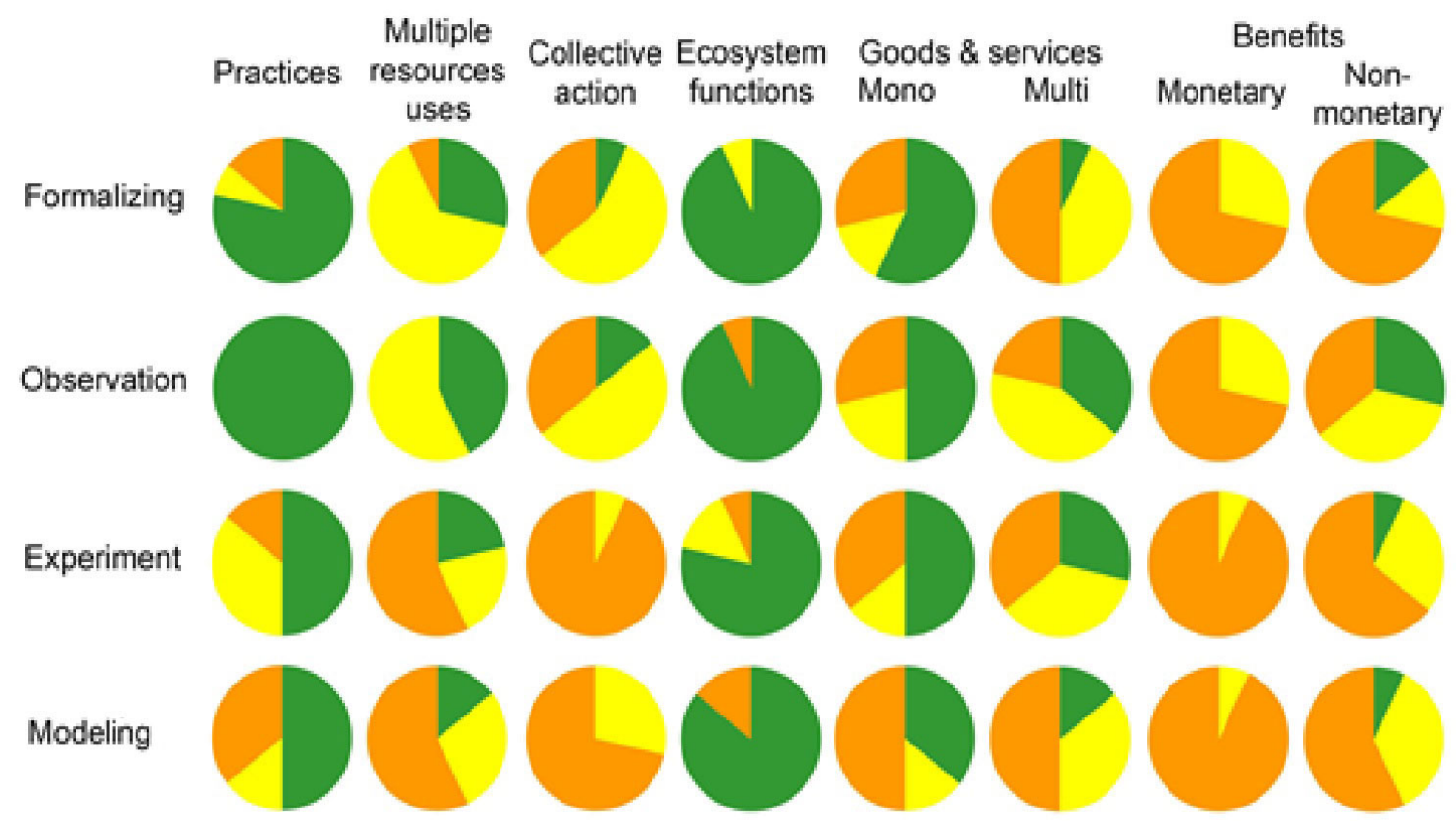

The emergence of social-ecological perspectives within the LTER initiative emerged from the integration of land-use perspectives, the inclusion of new disciplines, particularly from the social sciences and humanities, and the development of interdisciplinary research (Collins et al. 2011). The propulsion of SES theoretical background within the LTER network led to at least five major changes: (1) anthropogenic drivers, initially perceived as "disturbances" that should be minimized in LTER, became of special interest in LTSER with their own dynamics and feedback loops (Mirtl et al. 2013); (2) the complexity of the systems under study increased dramatically, as ecosystems and SESs are both complex adaptive systems (Folke et al. 2005, Levin et al. 2013); (3) conceptual frameworks included explicit interactions between the social and ecological/biophysical elements leading to new research questions, e.g., citizen viewpoints (Mirtl et al. 2013); (4) scientists eventually shifted from being perceived as objective, detached experts delivering knowledge in LTER sites to being stakeholders among the many that learn about and contribute to managing complex adaptive systems, because they are often involved in the decision-making process in the LTSER platforms and sites (Waltner-Toews et al. 2003); and (5) in LTSER, policies became hypotheses, and management actions represented ongoing learning experiments to test these hypotheses (Ostrom 2009).

However, we believe that moving from LTER to LTSER has not been fully achieved: current SES frameworks are not explicit enough to tackle present challenges. We need further tools to develop policies enhancing the sustainability and resilience of SESs. Beyond theoretical frameworks that are already available (Folke et al. 2005, Daily et al. 2009), we need operational frameworks that provide an adequate overview of the problems, associated causes, and resulting effects, thus helping to "organize diagnostic, descriptive, and prescriptive inquiry" as suggested by McGinnis and Ostrom (2014). In SES frameworks, the widely used notion of "driver" is challenged: land-use change is traditionally seen as a "human" driver, whereas it can result from social-ecological processes (Lambin et al. 2001); the resulting landscape should be considered as the holistic context and provides indicators of social-ecological interactions (Wu and David 2002, Benoît et al. 2012). Similarly, even though ESs are commonly present within most SES frameworks, the links between SESs and ESs are seldom explicit (Binder et al. 2013, Förster et al. 2015), and so are the human dimensions of ESs (Spangenberg et al. 2015).

\section{OPERATIONALIZING THE CONCEPTUAL FRAMEWORK WITHIN RESEARCH INFRASTRUCTURES}

To develop our LTSER approach in the French network, we initially used Collins's framework (Collins et al. 2011) as a basis, distinguishing between the social and biophysical templates. However, given the prominence of the biophysical template in many sites of our network, we focused our efforts on the social template (Fig. 2). For instance, values are often neglected in the 
Fig. 3. Use of the social-ecological system framework developed for the French LTSER network (Zones Ateliers) to illustrate the diversity of components underlying human-elephant coexistence issues, based on examples drawn from a long-term research in and around Hwange National Park (Zone Atelier Hwange, http://www.za-hwange.cnrs.fr), western Zimbabwe. The area, classified as agro-ecological region IV and V, is characterized by low fertility soils (mostly Kalahari sands) and erratic low annual rainfall (606 mm, inter-annual CV $=25 \%$ ). The current climatic trend of increasing drought severity (Chamaillé-Jammes et al. 2007) is constraining faring options and forcing adaptive land-use option. In a context of proximity to protected areas. The villagers rely essentially on subsistence farming and natural resource harvesting. HNP, a key protected area from the Kavango-Zambezi TFCA, hosts one the highest densities of free-ranging African elephants (A) in the world (Chamaillé-Jammes et al. 2009). (B) Ecosystem services provided by elephant as perceived by local communities living with them (positive services, 74\%, shown in bright darker colours, negative ones in lighter colours) (Guerbois 2012). Data was extracted from anonymous essays written by 54 village heads in nine villages on the edge of Hwange National Park. (C) Level of damage on crops from 30 intensively monitored fields in Magoli (De Garine-Wichatitsky et al. 2013). Overall, the level of livestock damages superseded those from elephant, clustered near the PAs. (D) Problem Animal Control (PAC) of elephant as a conventional response to crop raiding, and meat sharing as an advertised benefit. (E) The Social Network Analysis of the stakeholders association forum, showing an attempt to foster collective action and adaptive governance (Guerbois et al. Unpublished ms). (F,G) Farmers' field damage level strongly depends on the guarding activity of their neighbours, combined with their own effort (Feff) and the presence of well-used elephant path close to the field (Guerbois et al. 2012). (H) Seasonal variations in space use by elephants (orange kernels) at the edge of the farming area mainly constrained by surface water availability (blue dots) and human disturbance, here exemplified by herding strategies inside the Forest area (Purple kernel) (Vall-Fox et al. 2018). Conventional approaches to HEC focus on why elephant move in farming land (H), the level of damage (C) and the efficiency of active mitigation measures (D), though follow-up of the distribution process is rare. We advocate that the roots for coexistence are often present in local communities and that effort should be put on promoting the positive services (B) and existing collective actions and local governance initiatives (F) rather than mitigating negative services. A better comprehension of stakeholders interactions should facilitate adaptive governance (E). The SES lense is a useful tool to explore the diversity of linkages defining the interface between human and wildlife, and exposes alternative options to the 'commandand-control' approach to mitigating conflicts, focusing on endogenous processes, social cohesion, soft-edges and adaptive comanagement.

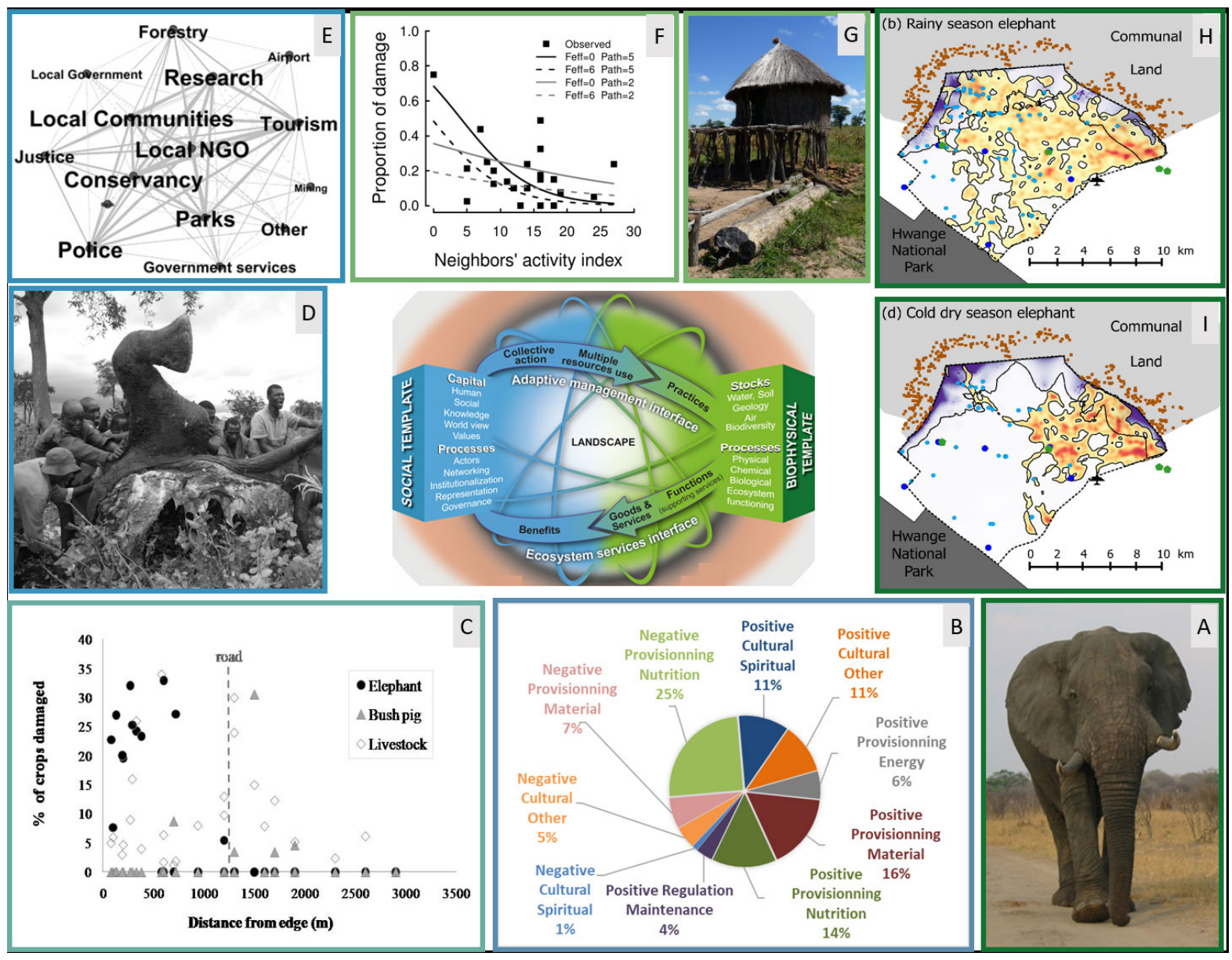


SES literature (Jones et al. 2016), particularly relational values that bind humans with ecosystems beyond the intrinsic and instrumental values of ecosystems. Values are also a fundamental aspect of cognition, so mental models should provide key insights into the social dimension of coupled SESs (Lynam and Brown 2011). In fact, sense of place (Chapin et al. 2012) and place attachment (Gosling and Williams 2010) are shown to be critical in explaining conservation-minded behavior and ecosystem stewardship. In the Hwange LTSER, we found that people rooted in the area had fewer conflicting views on wildlife and conservation than those who moved to the area in search of direct benefits from the protected areas or the natural resources (Guerbois et al. 2013). The explicit position of knowledge, values, and worldviews in our framework aims at underlining their crucial role in designing action-oriented research and thus addressing sustainability and conservation issues (Tengö et al. 2017). It is also a reminder that some knowledge and value systems (mostly indigenous) may have intrinsic elements and principles of environmental stewardship, emphasizing the need for some hybridization to foster innovation (Clark et al. 2016). Local rules for natural resource harvesting can thus be derived from negotiation between traditional authorities, economic actors, scholars, and local government services and result in new practices that can be inspired by traditional practices, as in the case of the Sikumi Forest in the Hwange LTSER (Guerbois et al. 2012, Guerbois and Fritz 2017).

A second major way to operationalize the framework is to apply it to landscapes that act both as contexts and outcomes (Fig. 1). This means using RIs that operate at the landscape level. Indeed, landscapes both condition and result from social and ecological interactions (Lambin et al. 2001). Moreover, through feedbacks, they contextualize and support SES dynamics. Landscapes are often seen as a societal outcome of land-use decisions (Ostrom et al. 2007). They may also be viewed as cultural (Haberl et al. 2006), as well as social-ecological products, emerging from coevolutionary interactions between people and ecosystems in ways that maintain biodiversity and provide humans with goods and services necessary for their well-being ( $\mathrm{Gu}$ and Subramanian 2014). In the Rhône River LTSER, thanks to strong interactions among multiple stakeholders over decades, models were run to predict the ecological impacts of a unique river restoration program while taking into account social values and public expectations in several riverine landscapes. In return, restoration measures benefited the ecology of the river, improved generic ecological knowledge, deeply renewed social links with the river, and influenced future management plans and practices (Lamouroux et al. 2015). In our framework, we consider landscapes not only as evolving social-ecological contexts but also as the nucleus of social-ecological dynamics across scales (see Fig. 3 for an example). We thus use all dimensions of landscapes, i.e., material, resource based, immaterial, cultural, functional, and scenic, to support place-based research. Landscapes are spatially nested hierarchies and can be effectively studied as such (Wu and David 2002). Including landscape in our conceptual framework allows it to become a flexible and integrative object for actors at all scales. In SESs, as in most complex systems, scale is a critical issue, including both temporal and spatial scales, as well as both patterns and processes (Redman et al. 2004). These scale issues occur in both social and ecological components, but they are critically contingent to adaptive management because cross-scale interaction mismatches may lead to SES vulnerability (Redman et al. 2004, Cumming et al. 2013). Therefore, scale should be a primary focus of any study on SES adaptive management or transformation. We suggest in our framework that the use of a landscape lens should (1) help reduce the likelihood of scale mismatches and (2) allow us to explicitly address causes and consequences of landscape changes, which is crucial to render research useful for sustainability science. For instance, when addressing farmer/elephant (Loxodonta africana) coexistence in LTSER Hwange, the emphasis should not just focus on field damage or on mitigation strategies at the ward or district levels, but also integrate dynamics across scales, i.e., the household, farmland, and village scales (Guerbois et al. 2012). Other aspects of the human-elephant relationship, such as its significance for the community, the true cost of damage for livelihoods, local perceptions of elephants, and the value of elephants for the human community of interest, should also be taken into account (Guerbois et al. 2012). A shift toward sustainability will thus require considering not only the ecological landscapes but also social and political landscapes where the issues are raised (Fig. 3). This calls for rethinking the role of research and of an RI rooted in SESs where social-ecological processes are simultaneously studied. Such an RI must be deeply connected with institutions, must engage in public/collective actions with stakeholders and citizens, and should, in addition, be running for decades to identify the long-term dynamics of ecological and social processes, to address the conditions of well-being for all, across generations.

The third specificity of our framework that makes it operational is that the French LTSER platforms endorse an operational definition of ESs. We acknowledge that ESs are not simply a byproduct of ecosystems, but rather the result of a coproduction process, in which human societies attribute values and use human capital and technology to modify ecosystem processes and goods (see Collof et al. 2017), even unintentionally (Harrington et al. 2010, Mace et al. 2015). The second interface of our conceptual framework depicted in Figure 1 is the ES interface. The ES cascade formally links the two templates (Fig. 1) and makes the interdependencies between humans and natural systems explicit (Collins et al. 2011). Even if the ES concept has been widely criticized (Schröter et al. 2014), ESs were found by Binder et al. (2013) to be an explicit part of all SES frameworks. ESs are often seen as the central part of a cascade, with ecosystem properties (biophysical structure, natural capital, or stock) producing ecosystem functions (flows), which provide goods and services that impact human livelihoods (benefits or costs), in a specific value system (Haines-Young and Potschin 2010, Mace et al. 2015). ESs are also a normative way to identify enhanced socialecological interactions (Abson et al. 2014). However, despite the fact that the ES concept is widely used, it sometimes fails to deliver relevant knowledge for policy making, developing financial mechanisms, and operational decisions (Laurans et al. 2013). In addition, decision makers, governments, businesses, and the public are rarely taken into consideration when analyzing ESs (Daily et al. 2000, 2009). We argue that LTSER sites provide a perfect tool not only to operationalize the ES concept and use in policy making (Colloff et al. 2017), but also to share focus, terminology, and system representations among research fields 
and disciplines and with the various stakeholders present within the boundaries of a given LTSER site or platform (Collins et al. 2011). Detailed analyses of the ES cascade were carried out, for instance, in the LTSER Plaine \& Val de Sèvre (Bretagnolle et al. 2018), linking land use and pollinator abundance and distribution (Bretagnolle and Gaba 2015), the role of wild and domestic bees in crop pollination (Perrot et al. 2018), crop yield (Perrot et al. 2019), farmers' income (Catarino, Bretagnolle, Perrot, et al., unpublished manuscript), and pollinator socio-cultural value (Montoya et al. 2019). We also need a better understanding of linkages within bundles of ESs and particularly of how they are affected by policy (land-use policies especially) and decisionmaking processes of individual stakeholders. This approach was used successfully in several French LTSER sites and platforms to bring together various stakeholders and elaborate collectively innovative landscapes, focusing on bundles of ESs (Berthet et al. 2019). Viewing ESs through the SES lens imposes considering ESs as a tool for assessing a mission-oriented discipline (Cowling et al. 2008) with a policy aim in mind, whether it is produced on request from decision makers or not. We therefore plead for an explicit SES-based approach of ESs, embedding a systemic view of social, economic, and ecological processes taking place in LTSER sites. The interfaces should be dealt with jointly as coupling agents in social-ecological processes. They should thus be fully investigated in any LTSER program portfolio (Barnaud et al. 2018).

\section{NETWORKING LONG-TERM SOCIAL-ECOLOGICAL RESEARCH SITES AND PLATFORMS TO DELIVER SUSTAINABLE DEVELOPMENT POLICIES}

Overall, almost 5 years was necessary to structure the French LTSER network around the SES interface, formalize the framework, and assemble the various items and concepts. The framework is currently being applied successfully in all French LTSERs (see Fig. 3 for a detailed working example, and Bretagnolle et al. [2018] for another example). The framework allows us to explore various questions within the SES (Fig. 2) and to describe the boundaries of the SES being studied (Kansky et al. 2016). Our experience in structuring the network highlights three key features: First, adopting a common operational transdisciplinary conceptual framework is a powerful tool to address a portfolio of actions toward sustainability. Second, the RI offers a diversity of contrasting and complementary ecological and social situations over a wide range of SESs (Table 1, Fig. 2); the RI is thus organized as a network distributed along ecological (e.g., climate and ecosystem types) and socio-economic (e.g., livelihoods and urbanization) gradients (Table 1) that promote the emergence of comparisons and experimental approaches at every level of the SES, addressing research questions related to the key elements of the adaptive management interface (Fig. 2). Third, the use of the SES approach in the LTSER network implies the recognition of researchers among the stakeholders of the SES they study, thus contributing to, and sometimes initiating, socialecological experiments. The level of involvement of scientists as stakeholders also follows a gradient: In some cases, scientists may be a simple observer group, whereas in others they are active actors in action-oriented research sites, e.g., activists or simply participating in management committees. In a few cases, they may even become landscape managers, e.g., within the NATURA 2000 network or in LTSER Plaine \& Val de Sèvre (Berthet et al. 2012).
LTSER sites are therefore dynamic tools that can be adapted to new challenges and in which scientists, as stakeholders involved in collective action, must bear a clear definition of their exact roles, accepting that research is not neutral (Falck and Spangenberg 2014). For instance, we recently developed the concept of SES experiments (Gaba and Bretagnolle, unpublished manuscript) as a new tool for place-based research in which scientists perform experimental manipulation of some of the components of the SES. Such experiments were performed with farmers in LTSER Plaine \& Val de Sèvre (Gaba et al. 2018). Experimental approaches in policy interventions are strongly needed to design for performance evaluation and improvement of the SES over time (Daily et al. 2009). Recognizing scientists as stakeholders may ensure long-term persistence of SES research within LTSER sites. This, as in any long-term RI, is only guaranteed as long as researchers are committed and funding is sufficient.

Therefore, to move from concept to sustainable development policies of SESs, the example of the French LTSER network stresses that scientists and stakeholders need (1) to better define the key drivers, i.e., the processes underlying the interaction dynamics, at the interface between ecosystem and society, especially those acting at the landscape scale; and (2) to identify the adaptive management processes and pathways, in terms of practices and collective actions, to provide operational knowledge for policy makers.

Responses to this article can be read online at: http://www.ecologyandsociety.org/issues/responses. php/10989

\begin{abstract}
Acknowledgments:
The Institut Ecologie Environnement, from CNRS, has funded the French LTSER network over the past 15 years. We also thank ALLENVI for funding the SOERE RZA and, in particular, one or two workshops per year between 2013 and 2018. We thank Stéphane Cramet for his help in designing Figure 1. We also thank two anonymous reviewers and the editors for greatly improving our first draft with their comments.
\end{abstract}

\section{LITERATURE CITED}

Abson, D. J., H. von Wehrden, S. Baumgärtner, J. Fischer, J. Hanspach, W. Härdtle, H. Heinrichs, A. M. Klein, D. J. Lang, P. Martens, and D. Walmsley. 2014. Ecosystem services as a boundary object for sustainability. Ecological Economics 103:29-37. https://doi.org/10.1016/j.ecolecon.2014.04.012

Anderies, J. M., M. A. Janssen, and E. Ostrom. 2004. A framework to analyze the robustness of social-ecological systems from an institutional perspective. Ecology and Society $9(1): 18$. https://doi. org/10.5751/ES-00610-090118

Balvanera, P., I. Siddique, L. Dee, A. Paquette, F. Isbell, A. Gonzalez, J. Byrnes, M. I. O'Connor, B. A. Hungate, and J. N. Griffin. 2014. Linking biodiversity and ecosystem services: current uncertainties and the necessary next steps. BioScience 64:49-57. https://doi.org/10.1093/biosci/bit003 
Barnaud, C., E. Corbera, R. Muradian, N. Salliou, C. Sirami, A. Vialatte, J.-P. Choisis, N. Dendoncker, R. Mathevet, C. Moreau, V. Reyes-García, M. Boada, M. Deconchat, C. Cibien, S. Garnier, R. Maneja, and M. Antona. 2018. Ecosystem services, social interdependencies, and collective action: a conceptual framework. Ecology and Society 23(1):15. https://doi. org/10.5751/ES-09848-230115

Bennett, E. M., G. D. Peterson, and L. J. Gordon. 2009. Understanding relationships among multiple ecosystem services. Ecology Letters 12:1394-1404. https://doi.org/10.1111/ j.1461-0248.2009.01387.x

Benoît M., D. Rizzo, E. Marraccini, A. C. Moonen, M. Galli, S. Lardon, H. Rapey, C. Thenail, and E. Bonari. 2012. Landscape agronomy: a new field for addressing agricultural landscape dynamics. Landscape Ecology 27(10):1385-1394. https://doi. org/10.1007/s10980-012-9802-8

Berthet, E. T. A., V. Bretagnolle, S. Lavorel, R. Sabatier, M. Tichit, and B. Segrestin. 2019. Applying ecological knowledge to the innovative design of sustainable agroecosystems. Journal of Applied Ecology 56:44-51. https://doi.org/10.1111/1365-2664.13173

Berthet, E. T., V. Bretagnolle, and B. Segrestin. 2012. Analyzing the design process of farming practices ensuring little bustard conservation: lessons for collective landscape management. Journal of Sustainable Agriculture 36:319-336. https://doi. org/10.1080/10440046.2011.627988

Binder, C. R., J. Hinkel, P. W. G. Bots, and C. Pahl-Wostl. 2013. Comparison of frameworks for analyzing social-ecological systems. Ecology and Society 18(4):26. https://doi.org/10.5751/ ES-05551-180426

Brand, F. S., and K. Jax. 2007. Focusing the meaning(s) of resilience: resilience as a descriptive concept and a boundary object. Ecology and Society 12(1):23. https://doi.org/10.5751/ ES-02029-120123

Bretagnolle, V., E. Berthet, N. Gross, B. Gauffre, C. Plumejeaud, S. Houte, I. Badenhausser, K. Monceau, F. Allier, P. Monestiez, and S. Gaba. 2018. Towards sustainable and multifunctional agriculture in farmland landscapes: lessons from the integrative approach of a French LTSER platform. Science of the Total Environment 627:822-834. https://doi.org/10.1016/j.scitotenv.2018.01.142

Bretagnolle, V., and S. Gaba. 2015. Weeds for bees? A review. Agronomy for Sustainable Development 35(3):891-909. https://doi. org/10.1007/s13593-015-0302-5

Callahan, J. T. 1984. Long-term ecological research. BioScience 34:363-367. https://doi.org/10.2307/1309727

Carpenter, S. R., H. A. Mooney, J. Agard, D. Capistrano, R. S. DeFries, S. M. Díaz, T. Dietz, A. K. Duraiappah, A. A. OtengYeboah, H. M. Pereira, C. Perrings, W. V. Reid, J. Sarukhan, R. J. Scholes, and A. Whyte. 2009. Science for managing ecosystem services: beyond the Millennium Ecosystem Assessment. Proceedings of the National Academy of Sciences of the United States of America 106:1305-1312. https://doi.org/10.1073/ pnas.0808772106

Cash, D. W., W. Adger, F. Berkes, P. Garden, L. Lebel, P. Olsson, L. Pritchard, and O. Young. 2006. Scale and cross-scale dynamics: governance and information in a multilevel world. Ecology and Society 11(2):8. https://doi.org/10.5751/ES-01759-110208

Chaffin, B. C., H. Gosnell, and B. A. Cosens. 2014. A decade of adaptive governance scholarship: synthesis and future directions. Ecology and Society 19(3):56. https://doi.org/10.5751/ES-06824-190356

Chamaillé-Jammes, S., H. Fritz, and F. Murindagomo. 2007. Climate-driven fluctuations in surface-water availability and the buffering role of artificial pumping in an African savanna: potential implication for herbivore dynamics. Austral Ecology 32:740-748. https://doi.org/10.1111/j.1442-9993.2007.01761.x

Chamaillé-Jammes, S., M. Valeix, M. Bourgarel, F. Murindagomo, and H. Fritz. 2009. Seasonal density estimates of common large herbivores in Hwange National Park, Zimbabwe. African Journal of Ecology 47:804-808. https://doi.org/10.1111/ j.1365-2028.2009.01077.x

Chapin, F. S., III, S. R. Carpenter, G. P. Kofinas, C. Folke, N. Abel, W. C. Clark, P. Olsson, D. M. Stafford Smith, B. Walker, O. R. Young, F. Berkes, R. Biggs, J. M. Grove, R. L. Naylor, E. Pinkerton, W. Steffen, and F. J. Swanson. 2010. Ecosystem stewardship: sustainability strategies for a rapidly changing planet. Trends in Ecology \& Evolution 25(4):241-249. https://doi. org/10.1016/j.tree.2009.10.008

Chapin, F. S., III, A. F. Mark, R. A. Mitchell, and K. J. M. Dickinson. 2012. Design principles for social-ecological transformation toward sustainability: lessons from New Zealand sense of place. Ecosphere 3:1-22. https://doi.org/10.1890/ ES12-00009.1

Church, J. M. 2018. Pathways of adaptation to climate change: analysis and transformation of the governance system of the Ardennes mountain area. Journal of Alpine Research 106(3):1-14. https://doi.org/10.4000/rga.5108

Clark, W. C., T. P. Tomich, M. van Noordwijk, D. Guston, D. Catacutan, N. M. Dickson, and E. McNie. 2016. Boundary work for sustainable development: natural resource management at the Consultative Group on International Agricultural Research (CGIAR). Proceedings of the National Academy of Sciences of the United States of America 113:4615-4622. https://doi. org/10.1073/pnas.0900231108

Collins, S. L., S. R. Carpenter, S. M. Swinton, D. E. Orenstein, D. L. Childers, T. L. Gragson, N. B. Grimm, J. M. Grove, S. L. Harlan, J. P. Kaye, A. K. Knapp, G. P. Kofinas, J. J. Magnuson, W. H. McDowell, J. M. Melack, L. A. Ogden, G. P. Robertson, M. D. Smith, and A. C. Whitmer. 2011. An integrated conceptual framework for long-term social-ecological research. Frontiers in Ecology and the Environment 9:351-357. https://doi.org/10.1890/100068

Colloff, M. J., S. Lavorel, L. E. van Kerkhoff, C. A. Wyborn, I. Fazey, R. Gorddard, G. M. Mace, W. B. Foden, M. Dunlop, I. C. Prentice, J. Crowley, P. Leadley, and P. Degeorges. 2017. Transforming conservation science and practice for a postnormal world. Conservation Biology 31:1008-1017. https://doi.org/10.1111/ cobi.12912

Cowling, R. M., B. Egoh, A. T. Knight, P. J. O'Farrell, B. Reyers, M. Rouget, D. J. Roux, A. Welz, and A. Wilhelm-Rechman. 2008. An operational model for mainstreaming ecosystem services for implementation. Proceedings of the National Academy of Sciences 
of the United States of America 105:9483-9488. https://doi. org/10.1073/pnas.0706559105

Cumming, G. S., P. Olsson, F. S. Chapin III, and C. S. Holling. 2013. Resilience, experimentation, and scale mismatches in socialecological landscapes. Landscape Ecology 28:1139-1150. https:// doi.org/10.1007/s10980-012-9725-4

Daily, G. C., S. Polasky, J. Goldstein, P. M. Kareiva, H. A. Mooney, L. Pejchar, T. H. Ricketts, J. Salzman, and R. Shallenberger. 2009. Ecosystem services in decision making: time to deliver. Frontiers in Ecology and the Environment 7:21-28. https://doi.org/10.1890/080025

Daily, G. C., T. Söderqvist, S. Aniyar, K. Arrow, P. Dasgupta, P. R. Ehrlich, C. Folke, A. M. Jansson, B.-O. Jansson, N. Kautsky, S. Levin, J. Lubchenco, K.-G. Mäler, D. Simpson, D. Starrett, D. Tilman, and B. Walker. 2000. The value of nature and the nature of value. Science 289:395-396. https://doi.org/10.1126/

science.289.5478.395

Dearing, J. A., R. Wang, K. Zhang, J. G. Dyke, H. Haberl, M. S. Hossain, P. G. Langdon, T. M. Lenton, K. Raworth, S. Brown, J. Carstensen, M. J. Cole, S. E. Cornell, T. P. Dawson, C. P. Doncaster, F. Eigenbrod, M. Flörke, E. Jeffers, A. W. Mackay, B. Nykvist, and G. M. Poppy. 2014. Safe and just operating spaces for regional social-ecological systems. Global Environmental Change 28:227-238. https://doi.org/10.1016/j.gloenvcha.2014.06.012

de Garine-Wichatitsky, M., H. Fritz, P. Chaminuka, A. Caron, C. Guerbois, D. M. Pfukenyi, C. Matema, F. Jori, and A. Murwira. 2013. Consequences of animals crossing the edges of transfrontier parks. Pages 137-162 in J. Andersson, M. de Garine-Wichatitsky, D. Cumming, V. Dzingirai, and K. Giller, editors. Transfrontier conservation areas: people living on the edge. Routledge, Oxford, UK. https://doi.org/10.4324/9781315147376-8

Ellis, E. C. 2015. Ecology in an anthropogenic biosphere. Ecological Monographs 85:287-331. https://doi.org/10.1890/14-2274.1

Ellis, E. C., K. K. Goldewijk, S. Siebert, D. Lightman, and N. Ramankutty. 2010. Anthropogenic transformation of the biomes, 1700 to 2000. Global Ecology and Biogeography 19:589-606. https://doi.org/10.1111/j.1466-8238.2010.00540.x

Falck, W. E., and J. H. Spangenberg. 2014. Selection of social demand-based indicators: EO-based indicators for mining. Journal of Cleaner Production 84:193-203. https://doi. org/10.1016/j.jclepro.2014.02.021

Feldman, M. S., and W. J. Orlikowski. 2011. Theorizing practice and practicing theory. Organization Science 22:1240-1253. https:// doi.org/10.1287/orsc.1100.0612

Folke, C. 2006. Resilience: the emergence of a perspective for social-ecological systems analyses. Global Environmental Change 16:253-267. https://doi.org/10.1016/j.gloenvcha.2006.04.002

Folke, C., T. Hahn, P. Olsson, and J. Nornerg. 2005. Adaptive governance of social-ecological systems. Annual Review of Environment and Resources 30:441-473. https://doi.org/10.1146/ annurev.energy.30.050504.144511

Förster, J., J. Barkmann, R. Fricke, S. Hotes, M. Kleyer, S. Kobbe, D. Kübler, C. Rumbaur, M. Siegmund-Schultze, R. Seppelt, J. Settele, J. H. Spangenberg, V. Tekken, T. Václavík, and H.
Wittmer. 2015. Assessing ecosystem services for informing landuse decisions: a problem-oriented approach. Ecology and Society 20(3):31. https://doi.org/10.5751/ES-07804-200331

Gaba, S., J. Caneill, B. Nicolardot, R. Perronne, and V. Bretagnolle. 2018. Crop competition in winter wheat has a higher potential than farming practices to regulate weeds. Ecosphere 9 (10):e02413. https://doi.org/10.1002/ecs2.2413

Gosling, E., and K. J. H. Williams. 2010. Connectedness to nature, place attachment and conservation behaviour: testing connectedness theory among farmers. Journal of Environmental Psychology 30:298-304. https://doi.org/10.1016/j.jenvp.2010.01.005

Gu, H., and S. M. Subramanian. 2014. Drivers of change in socioecological production landscapes: implications for better management. Ecology and Society 19(1):41. https://doi. org/10.5751/ES-06283-190141

Guerbois C. 2012. Considering protected areas in the dynamics of socio-ecological systems for the integrated and sustainable conservation of African wildlife. Dissertation. Muséum National d'Histoire Naturelle, Paris, France.

Guerbois, C., E. Chapanda, and H. Fritz. 2012 Combining multiscale socio-ecological approaches to understand the susceptibility of subsistence farmers to elephant crop raiding on the edge of a protected area. Journal of Applied Ecology 49:1149-1158. https:// doi.org/10.1111/j.1365-2664.2012.02192.X

Guerbois, C., A.-B. Dufour, G. Mtare, and H. Fritz. 2013. Insights for integrated conservation from attitudes of people toward protected areas near Hwange National Park, Zimbabwe. Conservation Biology 27:844-855. https://doi.org/10.1111/ cobi. 12108

Guerbois, C., and H. Fritz. 2017. Patterns and perceived sustainability of provisioning ecosystem services on the edge of a protected area in times of crisis. Ecosystem Services 28B:196-206. https://doi.org/10.1016/j.ecoser.2017.11.010

Haberl, H., V. Winiwarter, K. Andersson, R. U. Ayres, C. Boone, A. Castillo, G. Cunfer, M. Fischer-Kowalski, W. R. Freudenburg, E. Furman, R. Kaufmann, F. Krausmann, E. Langthaler, H. Lotze-Campen, M. Mirtl, C. L. Redman, A. Reenberg, A. Wardell, B. Warr, and H. Zechmeister. 2006. From LTER to LTSER: conceptualizing the socioeconomic dimension of longterm socioecological research. Ecology and Society 11(2):13. https://doi.org/10.5751/ES-01786-110213

Haines-Young, R., and M. Potschin. 2010. The links between biodiversity, ecosystem services and human well-being. Pages 110-139 in D. G. Raffaelli and C. L. J. Frid, editors. Ecosystem ecology: anew synthesis. Cambridge University Press, Cambridge, UK. https://doi.org/10.1017/CBO9780511750458.007

Hamann, M., R. Biggs, and B. Reyers. 2015. Mapping socialecological systems: identifying 'green-loop' and 'red-loop' dynamics based on characteristic bundles of ecosystem service use. Global Environmental Change 34:218-226. https://doi. org/10.1016/j.gloenvcha.2015.07.008

Harrington, R., C. Anton, T. P. Dawson, F. de Bello, C. K. Feld, J. R. Haslett, T. Kluvánkova-Oravská, A. Kontogianni, S. Lavorel, G. W. Luck, M. D. A. Rounsevell, M. J. Samways, J. 
Settele, M. Skourtos, J. H. Spangenberg, M. Vandewalle, M. Zobel, and P. A. Harrison. 2010. Ecosystem services and biodiversity conservation: concepts and a glossary. Biodiversity and Conservation 19:2773-2790. https://doi.org/10.1007/ $\underline{\text { s10531-010-9834-9 }}$

Holling, C. S. 2001. Understanding the complexity of economic, ecological, and social systems. Ecosystems 4:390-405. https://doi. org/10.1007/s10021-001-0101-5

Jahn, T., M. Bergmann, and F. Keil. 2012. Transdisciplinarity: between mainstream and marginalization. Ecological Economics 79:1-10. https://doi.org/10.1016/j.ecolecon.2012.04.017

Jones, N. A., S. Shaw, H. Ross, K. Witt, and B. Pinner. 2016. The study of human values in understanding and managing socialecological systems. Ecology and Society 21(1):15. https://doi. org/10.5751/ES-07977-210115

Kansky, R., M. Kidd, and A. T. Knight. 2016. A wildlife tolerance model and case study for understanding human wildlife conflicts. Biological Conservation 201:137-145. https://doi.org/10.1016/j. biocon.2016.07.002

Kofinas, G. P. 2009. Adaptive co-management in social-ecological governance. Pages 77-101 in C. Folke, G. Kofinas, and F. Chapin, editors. Principles of ecosystem stewardship. Springer, New York, New York, USA. https://doi.org/10.1007/978-0-387-73033-2 4

Lambin, E. F., B. L. Turner, H. J. Geist, S. B. Agbola, A. Angelsen, J. W. Bruce, O. T. Coomes, R. Dirzo, G. Fischer, C. Folke, P. S. George, K. Homewood, J. Imbernon, R. Leemans, X. Li, E. F. Moran, M. Mortimore, P. S. Ramakrishnan, J. F. Richards, H. Skånes, W. Steffen, G. D. Stone, U. Svedin, T. A. Veldkamp, C. Vogel, and J. Xu. 2001. The causes of land-use and land-cover change: moving beyond the myths. Global Environmental Change 11:261-269. https://doi.org/10.1016/S0959-3780(01)00007-3

Lamouroux, N., J. A. Gore., F. Lepori, and B. Statzner. 2015. The ecological restoration of large rivers needs science-based, predictive tools meeting public expectations: an overview of the Rhône project. Freshwater Biology 60:1069-1084. https://doi. org/10.1111/fwb.12553

Lascoumes, P., and P. Le Gales. 2007. Introduction: understanding public policy through its instruments - from the nature of instruments to the sociology of public policy instrumentation. Governance 20:1-21. https://doi.org/10.1111/ j.1468-0491.2007.00342.X

Laurans, Y., A. Rankovic, R. Billé, R. Pirard, and L. Mermet. 2013. Use of ecosystem services economic valuation for decision making: questioning a literature blindspot. Journal of Environmental Management 119:208-219. https://doi.org/10.1016/ j.jenvman.2013.01.008

Lescourret, F., D. Magda, G. Richard, A. F. Adam-Blondon, M. Bardy, J. Baudry, I. Doussan, B. Dumont, F. Lefèvre, I. Litrico, R. Martin-Clouaire, B. Montuelle, S. Pellerin, M. Plantegenest, E. Tancoigne, A. Thomas, H. Guyomard, and J. F. Soussana. 2015. A social-ecological approach to managing multiple agroecosystem services. Current Opinion in Environmental Sustainability 14:68-75. https://doi.org/10.1016/j.cosust.2015.04.001
Levin, S. A. 1998. Ecosystems and the biosphere as complex adaptive systems. Ecosystems 1:431-436. https://doi.org/10.1007/ $\underline{\mathrm{s} 100219900037}$

Levin, S., T. Xepapadeas, A. S. Crépin, and J. Norberg. 2013. Social-ecological systems as complex adaptive systems: modeling and policy implications. Environment and Development Economics 18:111-132. https://doi.org/10.1017/S1355770X12000460

Lewis, S. L., and M. A. Maslin. 2015. Defining the Anthropocene. Nature 519:171-180. https://doi.org/10.1038/nature14258

Lynam, T., and K. Brown. 2011. Mental models in humanenvironment interactions: theory, policy implications, and methodological explorations. Ecology and Society 17(3):24. https://doi.org/10.5751/ES-04257-170324

Mace, G. M., R. S. Hails, P. Cryle, J. Harlow, and S. J. Clarke. 2015. REVIEW: towards a risk register for natural capital. Journal of Applied Ecology 52:641-653. https://doi.org/10.1111/1365-2664.12431

Matson, P., W. C. Clark, and K. Andersson. 2016. Pursuing sustainability: a guide to the science and practice. Princeton University Press, Princeton, New Jersey, USA.

Mauz, I., T. Peltola, C. Granjou, S. van Bommel, and A. Buijs. 2012. How scientific visions matter: insights from three long-term socio-ecological research (LTSER) platforms under construction in Europe. Environmental Science \& Policy 19-20:90-99. https:// doi.org/10.1016/j.envsci.2012.02.005

Mazé, C., T. Dahou, O. Ragueneau, A. Danto, E. Mariat-Roy, M. Raimonet, and J. Weisbein. 2017. Knowledge and power in integrated coastal management. For a political anthropology of the sea combined with sciences of the marine environment. Comptes Rendus Geoscience 349(6-7):359-368. https://doi. org/10.1016/j.crte.2017.09.008

McGinnis, M. D., and E. Ostrom. 2014. Social-ecological system framework: initial changes and continuing challenges. Ecology and Society 19(2):30. https://doi.org/10.5751/ES-06387-190230

Mirtl, M., D. E. Orenstein, M. Wildenberg, J. Peterseil, and M. Frenzel. 2013. Development of LTSER platforms in LTEREurope: challenges and experiences in implementing place-based long-term socio-ecological research in selected regions. Pages 409-442 in S. J. Singh, H. Haberl, M. Chertow, M. Mirtl, and M. Schmid, editors. Long term socio-ecological research. HumanEnvironment Interactions 2. Springer, Dordrecht, The Netherlands. https://doi.org/10.1007/978-94-007-1177-8 17

Montoya, D., B. Haegeman, S. Gaba, C. de Mazancourt, V. Bretagnolle, and M. Loreau. 2019. Trade-offs in provisioning and stability of multiple ecosystem services in agroecosystems. Ecological Applications 29(2):e01853. https://doi.org/10.1002/ eap.1853

Nassl, M., and J. Löffler. 2015. Ecosystem services in coupled social-ecological systems: closing the cycle of service provision and societal feedback. Ambio 44:737-749. https://doi. org/10.1007/s13280-015-0651-y

Olson, M. 1971. The logic of collective action: public goods and the theory of groups. Harvard University Press, Cambridge, Massachusetts, USA. 
Olsson, P., C. Folke, and F. Berkes. 2004. Adaptive comanagement for building resilience in social-ecological systems. Environmental Management 34:75-90. https://doi.org/10.1007/s00267-003-0101-7

Ostrom, E. 1990. Governing the commons: the evolution of institutions for collective action. Cambridge University Press, New York, New York, USA. https://doi.org/10.1017/CBO9780511807763

Ostrom, E. 2009. A general framework for analyzing sustainability of social-ecological systems. Science 325:419-422. https://doi.org/10.1126/science.1172133

Ostrom, E., M. A. Janssen, and J. M. Anderies. 2007. Going beyond panaceas. Proceedings of the National Academy of Sciences of the United States of America 104:15176-15178. https:// doi.org/10.1073/pnas.0701886104

Perrot, T., S. Gaba, M. Roncoroni, J. L. Gautier, and V. Bretagnolle. 2018. Bees increase oilseed rape yield under real field conditions. Agriculture, Ecosystems \& Environment 266:39-48. https://doi.org/10.1016/j.agee.2018.07.020

Perrot, T., S. Gaba, M. Roncoroni, J.-L. Gautier, A. Saintilan, and V. Bretagnolle. 2019. Experimental quantification of insect pollination on sunflower yield, reconciling plant and field scale estimates. Basic and Applied Ecology 34:75-84. https://doi. org/10.1016/j.baae.2018.09.005

Pimm, S. L., C. N. Jenkins, R. Abell, T. M. Brooks, J. L. Gittleman, L. N. Joppa, P. H. Raven, C. M. Roberts, and J. O. Sexton. 2014. The biodiversity of species and their rates of extinction, distribution and protection. Science 344:1246752. https://doi. org/10.1126/science. 1246752

Redman, C. L., J. M. Grove, and L. H. Kuby. 2004. Integrating social science into the Long-Term Ecological Research (LTER) Network: social dimensions of ecological change and ecological dimensions of social change. Ecosystems 7:161-171. https://doi. org/10.1007/s10021-003-0215-Z

Reyers, B., R. Biggs, G. S. Cumming, T. Elmqvist, A. P. Hejnowicz, and S. Polasky. 2013. Getting the measure of ecosystem services: a social-ecological approach. Frontiers in Ecology and the Environment 11:268-273. https://doi.org/10.1890/120144

Rissman, A. R., and S. Gillon. 2017. Where are ecology and biodiversity in social-ecological systems research? A review of research methods and applied recommendations. Conservation Letters 10:86-93. https://doi.org/10.1111/conl.12250

Rosenberg, S. W. 2007. Rethinking democratic deliberation: the limits and potential of citizen participation. Polity 39:335-360. https://doi.org/10.1057/palgrave.polity.2300073

Schröter, M., E. H. van der Zanden, A. P. E. van Oudenhoven, R. P. Remme, H. M. Serna-Chavez, R. S. de Groot, and P. Opdam. 2014. Ecosystem services as a contested concept: a synthesis of critique and counter-arguments. Conservation Letters 7:514-523. https://doi.org/10.1111/conl.12091

Spangenberg, J. H., C. Görg, and J. Settele. 2015. Stakeholder involvement in ESS research and governance: between conceptual ambition and practical experiences - risks, challenges and tested tools. Ecosystem Services 16:201-211. https://doi.org/10.1016/j. ecoser.2015.10.006
Tancoigne, E., M. Barbier, J.-P. Cointet and, G. Richard. 2014. The place of agricultural sciences in the literature on ecosystem services. Ecosystem Services 10:35-48. https://doi.org/10.1016/j. ecoser.2014.07.004

Tengö, M., R. Hill, P. Malmer, C. M. Raymond, M. Spierenburg, F. Danielsen, T. Elmqvist, and C. Folke. 2017. Weaving knowledge systems in IPBES, CBD and beyond-lessons learned for sustainability. Current Opinion in Environmental Sustainability 26-27:17-25. https://doi.org/10.1016/j.cosust.2016.12.005

United Nations Development Programme (UNDP). 2015. UNDP social and environmental standards. UNDP, New York, New York, USA. [online] URL: https://info.undp.org/sites/bpps/ SES_Toolkit/default.aspx

Valls-Fox, H., S. Chamaillé-Jammes, M. de Garine-Wichatitsky, A. Perrotton, N. Courbin, E. Miguel, C. Guerbois, A. Caron, A. Loveridge, B. Stapelkamp, M. Muzamba, and H. Fritz. 2018. Water and cattle shape habitat selection by wild herbivores at the edge of a protected area. Animal Conservation 21:365-375. https:// doi.org/10.1111/acv.12403

Waltner-Toews, D., J. J. Kay, C. Neudoerffer, and T. Gitau. 2003. Perspective changes everything: managing ecosystems from the inside out. Frontiers in Ecology and the Environment 1:23-30. https://doi.org/10.1890/1540-9295(2003)001[0023:PCEMEF]2.0. $\mathrm{CO} ; 2$

Wu, J., and J. L. David. 2002. A spatially explicit hierarchical approach to modeling complex ecological systems: theory and applications. Ecological Modelling 153:7-26. https://doi. org/10.1016/S0304-3800(01)00499-9 